\title{
Mathematics Teachers' Subject Matter Knowledge and Pedagogical Content Knowledge in Problem Posing
}

\author{
Yujin Lee ${ }^{{ }^{*}}$, Robert M. Capraro ${ }^{1}$, Mary Margaret Capraro ${ }^{1}$ \\ ${ }^{1}$ Texas A\&M University, USA \\ *CORRESPONDENCE: $\nabla$ yujinlee@tamu.edu
}

\begin{abstract}
Since the National Council of Teachers of Mathematics ([NCTM], 2000) and the National Research Council $([N R C], 2005)$ revealed that problem posing needed to be incorporated into mathematics classrooms, the importance of teachers' roles in problem posing has been emphasized in $\mathrm{K}-12$ mathematics curriculum because of instructors' impact on students' mathematical performance. In the present study, researchers investigated teachers' subject matter knowledge (SMK), knowledge of content and teaching (KCT), and knowledge of content and students (KCS) in terms of problem-posing. A qualitative study design and inductive analysis were used to gather and interpret data from interviews conducted with four mathematics teachers. Results indicated that participants had SMK of problem posing, but their actual problem-posing results did not reflect their SMK well. In terms of KCS and KCT, teachers were aware of the importance of problem posing for students' mathematical development but felt that there were several significant factors impeding the effective incorporation of problem posing within their classes. These findings underscore the importance of professional development for teacher pedagogical knowledge in problem posing.
\end{abstract}

Keywords: problem posing, subject matter knowledge, knowledge of content and teaching, knowledge of content and students, pedagogical content knowledge

\section{INTRODUCTION}

An awareness of the importance of problem posing in mathematics has begun to develop in recent decades among researchers and educators. The National Council of Teachers of Mathematics ([NCTM], 2000) and the National Research Council ([NRC], 2005) have stressed the need of incorporating problem-posing activities in mathematics classrooms for students' successful mathematical performance. This emphasis on increasing the presence of problem-posing in curriculum is a global trend. For example, the Korea has also prioritized student acquisition of problem-posing skills through its National Curriculum of Korea (2015), which was developed to give instructional attention to problem-posing. Teachers play a critical role in problem-posing activities. Teacher knowledge such as subject matter knowledge (SMK) and pedagogical content knowledge (PCK) have had a critical influence on students' mathematical understanding and achievement (Ball, Thames, \& Phelps, 2008). Therefore, teacher knowledge of problem posing must be considered and developed to improve students' success in problem-posing activities and mathematical performance. However, their ability to positively influence students' mathematics achievement through problem-posing instruction is highly contingent on their effectiveness in teaching the activity. Researchers have found that a number of teachers have difficulty teaching problem posing in their classrooms (Cankoy, 2010). The lack of teacher knowledge might impair teachers' teaching performance in problem-posing activities (Barlow \& Cates, 2006). Understanding teachers'

Article History: Received 24 March $2018 \bullet$ Revised 7 May $2018 \bullet$ Accepted 26 May 2018

(C) 2018 The Author(s). Open Access terms of the Creative Commons Attribution 4.0 International License (http://creativecommons.org/licenses/by/4.0/) apply. The license permits unrestricted use, distribution, and reproduction in any medium, on the condition that users give exact credit to the original author(s) and the source, provide a link to the Creative Commons license, and indicate if they made any changes. 
SMK and PCK could in relation to problem posing could have far reaching and lasting implications in the assessment and improvement of their teacher knowledge, thereby improving the problem posing and overall mathematical performance of their students as well.

\section{Problem Posing}

Problem posing is an effective mathematical activity for improving students' mathematical knowledge. In the process of problem posing, students are afforded opportunities to understand the complexities of mathematical concepts (Priest, 2009), transfer their understanding to their concrete knowledge (Bernardo, 2001), and apply this knowledge to their posed mathematics problems (Mestre, 2002). Research has indicated that this development of concrete, comprehensive mathematical knowledge through problem posing can influence students' mathematical academic achievement (Van Harpen \& Presmeg, 2013). For these reasons, NCTM (2000) and NRC (2005) stated that problem posing needs to be incorporated in curriculum to foster students' mathematical academic achievement. However, the criteria for categorizing problem-posing types, historically, has been highly dependent on the individual preferences of researchers (e.g. Brown \& Walter, 1990; Stickles, 2006); thus, systematic structuralization of problem posing types is needed. In the present study, problem posing referred to the act of formulating a problem (Stickles, 2006), and instances of problem posing were categorized into two types: problem generation and problem reformulation (Pelczer \& Rodriguez, 2011; Silver, 1994; Singer, 1994; Stickles, 2006). Problem generation and problem reformulation differ in their processes of formulation from the start of each respective process to the completion of a posed problem; therefore, it was necessary to examine them separately in the present study.

The primary educational purposes of teaching and learning problem generation and problem reformulation are different. Problem generation is a process by which a learner creates a new problem on his or her own using a given situation (Stickles, 2011). The given situation in problem generation is more informal than the given situation in problem reformulation. For example, asking students to formulate problems based on one triangle-shaped picture could be a problem-generation activity. This informal given situation leads students to consider their personal experiences, and the students have the opportunity to connect mathematics with these experiences and real-world situations (Silver, 1994). In the process of applying mathematical knowledge, students can structuralize their existing schema of mathematical concepts to incorporate new conceptual information and increase their creativity (Grundmeier, 2003). Problem reformulation is similar to problem generation in that the learner can structuralize concepts and increase his or her creativity in the process of analyzing and utilizing the given math problems; however, problem reformulation necessitates a greater focus on reflection of the existing problem (Lee, 2012). A given situation in problem reformulation is also referred to as a given problem. For example, rearranging numerical information, such as posing the mathematics problem from a given situation/problem "What is $2+3$ ?" to "What is $4+3$ ?", can be considered as a problem-reformulation activity. By utilizing the existing problem, the learner can expand his or her scope of thinking and reflect on the concepts that he or she had recently learned prior to the problem-posing activity (Stickles, 2006). In other words, use of problem generation primarily offers the opportunity for learners to foster their creativity, while use of problem reformulation predominantly allows learners to develop their reflective skills.

\section{Teacher Knowledge}

Teacher knowledge, including SMK and PCK, is the basis for teachers' instructional practices in their classroom. SMK has been defined as "emphasizing knowledge and understanding of facts, concepts, and principles and the ways in which they are organized, as well as knowledge about the discipline" (Even, 1993, p. 94). Researchers have found that insufficient SMK among teachers led their students to develop misconceptions, misunderstandings, and misinterpretations regarding the subject matter during instruction (Valanides, 2000). In addition, teachers who have higher SMK have more favorable attitudes toward their teaching than those who lack or have limited SMK (Barlow \& Cates, 2006; Quinn, 1997). These findings could indicate that SMK affects not only teachers' teaching practice but also their PCK (Ozden, 2008). Researchers have determined that teachers' PCK is highly related to students' academic achievement (Darling-Hammond, 2000). Therefore, teachers must develop and maintain sufficient and comprehensive SMK for the betterment of their students' mathematics performance (NCTM, 2000; Rizvi, 2004; Schmidt et al., 2009).

Pedagogical content knowledge (PCK) differs from SMK in the sense that it has a significant role in characterizing and identifying teachers' knowledge regarding their students' difficulty with subject matter and ability to connect mathematical ideas, use examples, provide explanations, and apply strategies when encountering mathematical concepts (Wagner, Speer, \& Rossa, 2007). Researchers found that PCK factors 


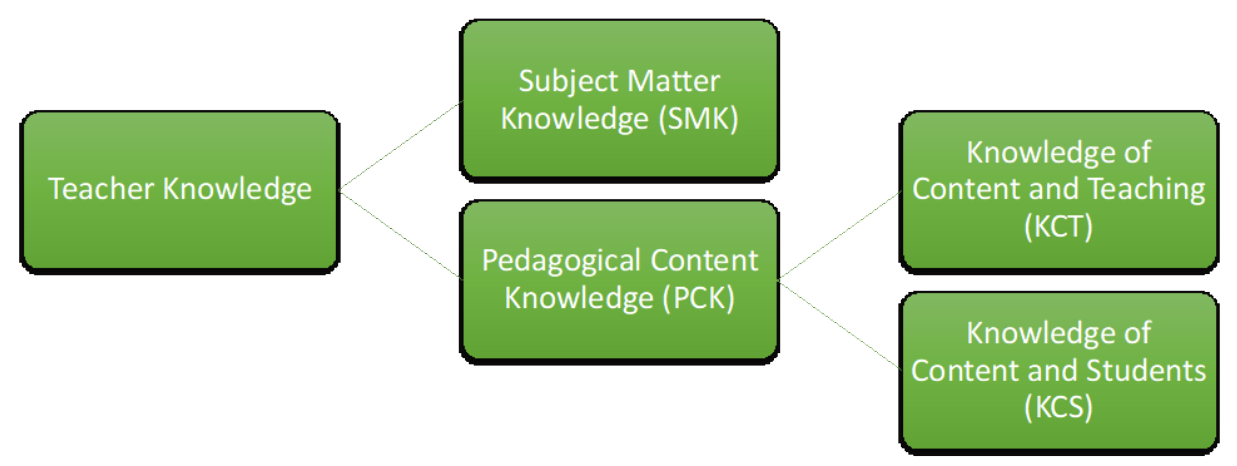

Figure 1. A theoretical framework of teacher knowledge

such as teachers' pedagogical preparation, their use of routines in the classroom, and their degree content coverage influenced students' academic achievement growth (Cankoy, 2010; Rowan, Correnti, \& Miller, 2002). Many researchers have attempted to find relationships between teacher knowledge and students' mathematical academic achievement (Wilson, Floden, \& Ferrini-Mundy, 2001, 2002) and have tried to connect PCK to student learning (Ball, Hill, \& Bass, 2005; Ball et al., 2008). Schulman (1986) introduced the term PCK and defined it as a "special amalgam of content and pedagogy that is uniquely the province of teachers, their own special form of professional understanding" (p. 227). Since Shulman's (1986) demonstration of the importance of teacher knowledge, attention to teacher knowledge has shifted over time from an analysis of SMK to PCK (Ball et al, 2008). This shift to PCK research has come with the development of various categorizations of PCK.

The subscales of PCK have been categorized differently depending on the researchers analyzing them. In particular, since Shulman (1986) introduced PCK, many researchers in mathematics education have described the subscales of PCK by extending Shulman's (1986) concept. Lannin et al. (2013) categorized PCK's subscales for teaching mathematics as teachers' knowledge of the following: curriculum for mathematics, assessment for mathematics, instructional strategies for mathematics, and student understanding within mathematics. In contrast, Hauk, Toney, Jackson, Nair, and Tsay (2014) considered PCK to include knowledge of discourse, curricular thinking, anticipatory thinking, and implementation thinking. Hill, Ball, and Schilling (2008) provided a categorization of both SMK and PCK subscales, dividing the concept of SMK into common content knowledge, knowledge at the mathematical horizon, and specialized content knowledge; and PCK into knowledge of curriculum, knowledge of mathematical content and students (KCS), and knowledge of mathematical content and teaching (KCT) (Ball et al., 2008). Although there are several variations of PCK, for this study, the researchers used the definitions of PCK, its subscales (KCT and KCS), and SMK as defined in the work of Hill et al. (2008). In particular, the researchers primarily focused on two components of PCK, namely, KCS and KCT in conjunction with SMK to determine teachers' proficiency in problem posing in relation to these branches of teacher knowledge. Figure 1 includes the theoretical framework of teacher knowledge for the present study.

\section{Teacher Knowledge in Problem Posing}

Teachers' competency and knowledge in using and teaching problem posing are influential factors that can influence students' conceptual understanding in problem posing. Instructors should have the capacity to generate and reformulate problems in order to provide relevant activities for students' learning. It is critical for teachers to acquire problem posing experiences if they intend to provide new and different forms of learning experiences to their students (Crespo \& Sinclair, 2008; Rowland, Huckstep, \& Thwaites, 2003; Singer \& Voica, 2012). Teachers were able to identify students' mathematical misconceptions through problem-posing proves as well as posed problems from the students (Koichu, Harel, \& Manaster, 2013). Teachers may benefit from problem-posing activities during their professional development experience to develop SMK (Barlow \& Cates, 2006). Recognizing teachers as critical agents in problem-posing activities for students is important (Silver, 1994). Thus, proper trainings for the teachers are critical. Despite of the importance of teacher's role, teachers had a narrow concept of problem posing. Since many teachers have not experienced problem posing when they were students or pre-service teachers, they tended to avoid problem posing or provide routinized exercises (Ball, 1990). Crespo (2003) indicated that teachers posed problems that were predictable, undemanding, ill- 
formulated, and unsolvable when they extended a given problem. The majority of the posed problems focused on memorization and procedural understanding rather than on mathematical reasoning and conceptual understanding (Stein, Smith, Henningsen, \& Silver, 2000). It is, therefore, important to broaden teacher knowledge in problem posing.

Teachers' lack of teacher knowledge can negatively influence not only the quality of the problem-posing activity itself but also students' problem-posing skills and results (Cankoy, 2010; Rowan et al., 2002; Wilson et al., 2001, 2002). Despite the importance of teacher knowledge in problem posing, a number of teachers have difficulties with building and implementing their SMK and PCK in problem posing. Therefore, the purpose of the present study was to investigate teachers' teacher knowledge including SMK and PCK (KCT and KCS) in problem posing. The findings of this study could provide researchers and educators with a better understanding and assessment of teachers' knowledge in relation to problem posing and signify a meaningful implication to improve that knowledge for the advancement of students' mathematics performance.

\section{METHODOLOGY}

The purpose of this study was to investigate teacher knowledge in problem posing. To accomplish this goal, researchers in the present study employed a qualitative interview design to gather data from participating teachers (Turner, 2010). Qualitative research was conducted through the use of semi-structured, open-ended interviews and two questionnaires, and inductive analysis was used to analyze the data.

\section{Participants}

To obtain greater insight into teacher knowledge, researchers interviewed four teachers who volunteered to respond to questions regarding their teacher knowledge of problem posing in an interview. Conducting teacher interviews enabled the researchers to develop an understanding of the interviewees' teacher knowledge and to begin viewing problem posing from the teachers' perspectives. All four teachers were intermediate-level middle/high school teachers in Korea. Kim had been teaching at a private middle school for two years while Seo had been teaching at a private high school for three years. Hyun had teaching experience at both levels, teaching at a private middle school for two years before she began teaching at a private high school, which she had taught at for four years. Yoon had been teaching in a public high school for five years. Each teacher had obtained a bachelor's degrees in mathematics education. In addition to her bachelor's degree, Seo also had a master's degree in mathematics education.

\section{Interviews}

Researchers chose to use a semi-structured, open-ended interview method to increase comparability of responses and to complete data for each teacher on the topics addressed in the interview (Patton, 2015). The interview questions were written out in advance and in the exact form in which they would be asked during the interviews. One researchers from the present study conducted each interview, and each participant was interviewed once for approximately one hour. All teachers were asked the same basic questions in the same order. Each teacher was allowed to skip questions that might have made her feel uncomfortable and was allowed to talk about ideas that arose that she felt important to include in her responses. When new or unanticipated ideas arose during an interview, the interviewer was free to explore those ideas. The interview questions were based on three categories about teacher knowledge: SMK, KCT, and KCS (see Table 1). During the interview, two mathematics questionnaires about problem posing were given to each participant to estimate the teacher's practical application of their problem-posing knowledge. The participants were told to pose as many problems using the questionnaires as possible during the a 10-minute period of the interview. The mathematics questionnaires used for this study were adopted from Lee's (2013) study. Questionnaire 1 included a story scenario for problem generation, and Questionnaire 2 included a mathematics problem for problem reformulation. The two questionnaires' story scenarios were based on real-world situations that were relatively familiar to the participants. The story scenarios and real-world situations were selected for the present study due to their effectiveness as problem-posing prompts; the use of unstructured situations like those employed in the questionnaires have been shown to attract problem posers' attention (English, 1998) and develop their flexibility of thinking by connecting mathematics with wide range of real-world scenarios (Bonotto, 2013). Teachers' responses were audio recorded during the interviews, which allowed the interviewer to gather a substantial amount of information within a relaxed environment (Merriam, 1998). The recorded interviews were later transcribed. Data gathered from interview responses were further supplemented through researchers' observation notes written during the interviews. 
Table 1. Open-Ended Interview Questions

I. Subject Matter Knowledge (SMK)

1. How do you define problem posing?

2. Can you explain the types of problem posing?

3. Can you make diverse problems, as many as possible, by using Questionnaire 1 and 2 ?

A. Explain the process and the reason why you posed these problems.

B. Can you analyze and categorize your posed problems?

[Questionnaire 1]

Nayeon's friends come over to her house. Her mom is going to bake cookies for them. She wants to give four cookies to each child, but so far, she has only baked three cookies. Therefore, she has to bake more cookies.

[Questionnaire 2]

The XX buffet restaurant charges 20,000 won (KRW) per person. They discount 5,000 won per reserved customer. Eugene's family reserved a table at this restaurant. Right before they left for the restaurant, they decided to take Eugene's grandparents along with them. When they were about to pay the bill after enjoying their meal, they found out that Eugene's grandparents could not get a discount since their names were not on the reservation list. In the end, they paid 115,000 won for everyone. In this case, how many people had made a reservation?

II. Knowledge of Content and Teaching (KCT)

1. What do you think about the types of problem posing that are present in mathematics curriculum and textbooks?

2. What do you think about incorporating problem posing your classes?

3. How do you incorporate problem posing in your class?

4. If you use problem posing to teach mathematics, how can you set up a lesson plan?

A. Whole-class activity or a Small-group activity

B. Which is the best to use in conjunction with problem posing: conceptualization, principle investigation, or problem solving?

5. Which one is your preference between mathematical situation and real-world situation in problem posing?

\section{Knowledge of Content and Students (KCS)}

1. What is your expectation if students pose problems using Questionnaire 1 and 2? Why?

2. Do you think there would be any differences between your results and students' result about Question 1 and 2 ? Why?

3. Do you think students require prior knowledge to pose a problem? If so, what kind of knowledge is required?

4. A student posed these problems. (see Appendix A and Appendix B for posed problems)

A. What do you think about them?

B. Are there any differences between your expectation and the student's actual results?

C. If some students cannot pose correct problems, how will you teach them?

D. What are the advantages and disadvantages for students in terms of educational benefits students may acquire by participating in problem-posing activities?

Table 2. Problem-Posing Codes

\begin{tabular}{llll}
\hline Factors & Content & Code \\
\hline Changing Scenario & $\bullet$ & Reconstructing the story of given scenarios & CS \\
\hline Changing Condition & $\bullet$ & $\begin{array}{l}\text { Changing the external conditions such as numbers while maintaining } \\
\text { the implied property of the given scenarios }\end{array}$ & CC \\
\hline $\begin{array}{l}\text { Changing Assumption } \\
\text { Changing Mathematical }\end{array}$ & $\bullet$ & Changing the implied property of the given scenarios & Generalizing the existing problem or applying a different level of \\
Structure & mathematical structure to the problem & CM \\
\hline
\end{tabular}

\section{Coding and Analysis}

Inductive analysis was used to search for patterns within the qualitative data, thereby discovering common themes through cross-case analysis (Patton, 2015). The transcriptions and teachers' posed problems were analysed through a process of open coding (Strauss \& Corbin, 1990). The coding procedure included two types: problem-posing codes and teacher-knowledge codes. The problem-posing codes were constructed to analyze the types of problem-posing strategies that teachers mentioned during the interview or used for their problemposing activities (see Table 2). The problem-posing codes could be selected multiple times for each problemposing result of the questionnaire.

The teacher knowledge codes were constructed to investigate teachers' responses. Table 3 contains the categories and components the researchers used to code teachers' responses. The first category was related to the object; objects were the teacher, student, or subject. The second category pertained to the reaction: 
Table 3. Components for Teacher Knowledge Codes

\begin{tabular}{cccccc}
\hline \multicolumn{1}{c}{ Object } & \multicolumn{2}{c}{ Perception } & \multicolumn{2}{c}{ Disposition } \\
\hline Teacher & $\mathrm{T}$ & Knowledge & $\mathrm{K}$ & Positive & $\mathrm{P}$ \\
\hline Student & $\mathrm{S}$ & Belief & $\mathrm{B}$ & Negative & $\mathrm{N}$ \\
\hline Subject & $\mathrm{C}$ & Activity & $\mathrm{A}$ & & \\
\hline
\end{tabular}

knowledge, belief, or activity. The third category involved positive perception and negative perception. Researchers chose the most applicable component from each category to analyze each response of the teachers. For example, if one of the teachers stated that "students have a positive perception about using problem posing activities in mathematics class", the researchers would assign the following code: "SAP" ("students": S from object, "positive perception": P from perception, "activities": A from disposition). Appendix C contains more examples of the teacher knowledge codes.

The qualitative data from transcriptions, problem-posing sheets, and researchers' observation notes were triangulated to establish internal validity (Anfara, Brown, \& Mangione, 2002). All researchers followed the same coding protocol independently, then evaluated any points of disagreement. The final codes were included in the current study once the disagreements were resolved. The inter-rater agreement was 0.95.

\section{RESULTS}

\section{Teachers' SMK in Problem Posing}

All four teachers defined problem posing as an activity in which one creates a problem by using the mathematical concept previously learned. They also identified both concepts of problem generation and problem reformulation as types of problem posing. When asked to explain problem generation and problem reformulation in detail and in comparison to each other, all teachers indicated that problem reformulation such as changing numbers and objects was easier than problem generation such as creating a problem from a real-world situation. When the interviewer asked about the types of problem posing, Hyun's response revealed that she was initially confused between types of problem-posing and types of problems. She appears to have not immediately grasped the concept of problem posing. When the interviewer mentioned the difference between a problem and problem posing, she then realized the difference between these two and started explaining the types of problem posing. This conversation demonstrates the potential for confusion, even among mathematics teachers, when discussing or attempting to understand the concept of problem posing.

\footnotetext{
Hyun: Types of problem posing...There are concept-understanding problems, knowledge-checking problems, computation problems, real-world problems, advanced-concept problems, and comprehensive problems.
}

Interviewer: Okay. What do you think about the differences between problems and problem posing?

Hyun: Um, oh, I was wrong. Problem posing is an activity. So, I can give a problem to students, and they make another problem. Or they can directly make a problem in a real-world situation.

There was a gap between the types of problem posing that teachers categorized and the types of problem posing that they used in their problem-posing tasks during the interview (see Table 4). In particular, the teachers' interview responses regarding problem-posing types indicate that the diversity of problem-posing types actually included in the problems they posed was less than the amount the teachers thought they would include. According to teachers' problem-posing results on the two questionnaires, one of which contained a problem generation question, and the other a problem reformation question (see Questionnaires 1 and 2 in Table 1), three of the four teacher posed types of problems that require a low-level of cognitive demand. For example, the three teachers used simple operations such as addition and multiplication. Despite their references to the importance and the role of problem posing in relation to complex mathematical concepts or thinking procedures, Kim and Yoon did not apply many types of problem-posing strategies when posing their problems. To complete Questionnaire 1, which was about problem generation, the teachers had to choose any number and apply it within the given situation. Yoon posed the following problem for Questionnaire 1 by adding a number to the problem to make it solvable and creating a question behind the situation: "If 15 friends visit the home, how many cookies should be baked?". Kim changed the scenario from the questionnaire's cookie situation to a carnation situation and added a number and question to solve the problem. In both Yoon and Kim's posed problems, there was no change of mathematical structure from that provided in Questionnaire 1. 
Table 4. Codes of Problem Posing about Teachers' Expectation and Reality

\begin{tabular}{ccc}
\hline Teachers & Expectation & Reality \\
\hline Kim & CC, CS, CM & CC, CS \\
\hline Seo & CC, CS, CA & CC, CS, CA \\
\hline Yoon & CC, CM & CC \\
\hline Hyun & CC, CS, CM & CM
\end{tabular}

Note. The meaning of each code is presented in Table 2

In contrast, Seo and Hyun made a noticeable effort to pose problems that diverged from aspects of the original structure and problem presented in the questionnaire. Seo added assumption and mathematical structure by stating "A cookie requires 2 almonds and 5 chocolate chips. Mom has 35 almonds and 79 chocolate chips. How many friends can be invited for cookies?" behind the given situation. Hyun also changed the assumptions and mathematical structure. Her added statement consisted of the follow scenario: " 7 friends visit the home. A cookie needs $200 \mathrm{~g}$ of flour. There are 2,500g of flour at home. How much more flour is needed?"

The teachers showed similar problem posing strategies in both problem generation and problem reformulation. Regarding to Questionnaire 2, which was about problem reformulation, Yoon merely changed the numbers (115,000 won to 201,600 won), and Kim changed the scenario (buffet restaurant to school cafeteria) and the numbers (5,000 won discount to 2,000 won discount). Hyun's problem had a different mathematical structure ("Eugene's grandparents could not get a discount." to "Eugene's grandparents also got a discount."). Seo changed the original scenarios of the questionnaire from a buffet situation to an amusement park situation and also changed the assumptions from the question about number of people to the full price of a ticket. The following was Hyun's posed problem for Questionnaire 2:

Eugene and 5 friends decided to go to the amusement park the day the midterm exam finished. The amusement park provides a 50\% discount ticket for a student with a student discount card. However, only 4 of them had cards. The 4 students who had cards paid the $50 \%$ discounted price. The other 2 students paid the full price. The total price was 80,000 won. What is the full price of a ticket?

Based on the teachers' interviews and their problem-posing results, the findings indicate that the participants did not have strong SMK in problem posing. In particular, most of them demonstrated a sufficient understanding of the definition of problem posing and the types of problem posing, but their actual problemposing activity results did not match with the SMK they demonstrated in their responses. Their posed problems contained a smaller number of problem-posing types than the number of types they mentioned when discussing their knowledge of problem posing.

\section{Teachers' KCT in Problem Posing}

Regarding problem posing in the curriculum and textbook, teachers indicated that problem posing was important, but a limitation existed in the current curriculum. Kim claimed that students needed experience in problem posing, but there was not enough time to complete problem-posing activities during a regular class period. She emphasized that simply changing numbers in problem posing should be avoided, and students should receive supplemental support to understand mathematical concepts through the experience of problem posing. She had incorporated problem posing in her class and had provided students with a changing condition activity from a given problem. Furthermore, she mentioned that the use of problem posing that involves adding and changing the conditions from a complex problem helped students to learn how to perform problem posing. Kim also discussed the importance of including both mathematical and real-world situations during the problem-posing process. Because engaging with and applying real-world situations was difficult for her students, Kim's choice of teaching method was to start with problem posing from the mathematical situation, and then expand to real-world situations once her students began to grasp the concepts and processes involved in problem posing. Seo suggested that the problem-posing types in existing textbooks were limited and that students were not familiar with solving real-world problems. Therefore, Seo believed that applying real-world problems to mathematics through problem posing could provide students with essential educational experiences that are typically lacking when teachers limit themselves and their students to textbook based problem posing. Despite this assertion, Seo mentioned that she only covered problem posing content that is present in the textbooks due to the limited available class time she had in which to cover problem posing. Below is the Seo's statement: 
Seo: I think most problem posing activities in the text book are about changing numbers...I do not think students are not good at solving a problem related to real-world situations, so it (problem posing) will be really helpful. I really want to encourage them (students) to do some problem-posing activities... You know, the reality is... It's hard to do this (problem posing)...I do not have enough time to do that.

All of the teachers except Yoon commonly conveyed positive perspectives regarding applying problem posing in their classes. The teachers in favour of problem posing suggested that the process should be used as a tool to identify mathematical concepts and increase student comprehension of those concepts. Hyun, however, viewed the educational benefits of problem posing from a broader scope, claiming that problem posing is not a tool for learning mathematical concepts, but for mathematically solving a real-world problem. According to Hyun, giving students an opportunity to think mathematically in the process of problem posing itself was more important than solving a problem and deriving a correct answer. From her perspective, the development of students' mathematical thinking proficiency should be regarded as the significance of teaching and learning. On the other hand, Yoon had a negative perspective regarding applying problem posing in classes. Yoon indicated that problem posing was not applicable to classes:

Yoon: I know it (problem posing) is important. But it's not easy to apply. If I use problem posing, I need assessment standards, but, I don't know what they are, and I don't think it is usable.

Differences between teachers emerged concerning the awareness of constructing problem-posing instructions. Kim preferred to construct a whole-class activity rather than creating a small-group activity or providing homework for problem posing. She also preferred to formulate the instructions involving problem posing before or after completing a problem-solving activity with the students because she thought that the students needed to know the relevant mathematical concepts and principles, best provided in a problemsolving activity, to pose a problem. Seo and Yoon preferred concentrating on whole-class activities, and were concerned that focusing on problem-posing activities would decreasing their students' interest in other mathematical concepts. Therefore, they wanted to minimize the application of problem-posing activities in their classes. To do so, they preferred to introduce the learning concept at the beginning of the class, and afterwards present the mathematical concept of a given situation, expanding thinking through problem posing. In general, the teachers were divided in their preference and reasons for the use of mathematical situations versus real-world situations in their problem posing instruction. Yoon chose mathematical situations, rather than a real-world situations, when introducing the problem-posing process in her class. On the other hand, several of the teachers preferred to use real-world situations for problem posing in class to develop students' diverse mathematical thinking.

\section{Teachers' KCS in Problem Posing}

During their interviews, the teachers mentioned that their experience with incorporating problem posing in their classrooms had led them to believe that problem-posing proficiency is highly related to mathematical proficiency. Results from previous studies indicate and affirm this relation between problem-posing proficiency and mathematical proficiency. Researchers have found that engaging in problem posing, which is an advanced mathematical activity, can develop students' mathematical thinking (Henningsen \& Stein, 1997), mathematical reasoning (Cai \& Hwang, 2002), mathematical knowledge, and creative thinking (Leung \& Silver, 1997), all of which are relevant components of mathematical proficiency. Furthermore, students' who exhibit efficient use of problem-posing strategies have improved their mathematical proficiency (Nicolaou \& Philippou, 2007). The educational benefits regarding proficiency in both mathematics and problem posing, however, appear to be reciprocal as studies have also shown that students' mathematical proficiency also influenced their problem posing (Cai \& Hwang, 2002). In the present study, the teachers emphasized the importance of concept-related prior knowledge, one component of mathematical proficiency, in particular when discussing the necessary knowledge and skills students must have to develop problem-posing proficiency. For example, Kim mentioned that problem posing could not be conducted without prior knowledge of the fundamental mathematical concepts and principles for problem posing. She also acknowledged that the basic knowledge required to pose problems may vary as problems can be composed of not only basic mathematical concepts, but also diverse principles of real-world situations or elements of other academic subjects. Therefore, Kim felt that students who engage in problem posing must have some basic form of mathematics proficiency to successfully pose a problem and improve their problem-posing proficiency. Likewise, she believed that students using prior knowledge in diverse scenarios can develop a thorough understanding of how to apply 
their mathematical knowledge, thereby improving their proficiency in mathematics. To expand her idea, she explained that students' mathematical proficiency can be fostered through several critical steps involved in posing a problem. In her experience, developing students' creativity through the diverse thinking processes required when posing problems situated in real-world scenarios in a given situation was often helpful in developing students' mathematical proficiency, and she believed that teaching students to simply replace the numbers of a given problem with their own is an insufficient teaching strategy. In addition, allowing her students to solve the problems they posed helped determine the factors within the students' knowledge and skills that required modification and complementation. Finally, having the students evaluate and modify their posed problems supported their development of thinking. Kim claimed that including each of these steps during a problem-posing activity helped foster students' mathematical proficiency.

In terms of the importance of problem solving in problem posing, the teachers had different opinions. Kim and Yoon indicated that problem posing involved problem solving while Seo and Hyun did not emphasize the problem solving in the problem-posing process. For example, Seo's perspective was that recognizing the internal concept of a given situation in the problem-posing process and trying to apply this concept to a realworld situation was an important factor of problem posing. Unlike Kim and Yoon, Seo and Hyun were not concerned about students deriving an incorrect answer in solving a posed problem; they believed that the development of one's problem-solving ability could be achieved by solving the problems in the textbook. Regardless of students' ability to correctly solve a posed problem, the two teachers felt that students learning to apply a given situation to pose a problem was the most important part of the problem-posing process. In other words, the purpose of problem posing was to understand the concept and to apply an experience to a problem situation. In this respect, the four teachers had different perceptions about evaluating students' incorrect posed problems.

To further examine the teachers' views regarding how to best evaluate students' incorrectly posed problems, they were given Appendices A and B, which contained a students' posed problems and were then asked to discuss the students' posed problems during their interviews. Kim and Yoon gave negative evaluations of the student's problems. Kim also suggested that problem solving should be concerned with modifying the posed problem through self-review or peer-review.

Kim: The student's thinking about the diverse situation is nice, but the answer is not correct. Also, he or she use another situation except a given condition. This is not what teachers want. So, I will take off points.

In contrast to Kim and Yoon's negative evaluations of the student's posed problems, Seo and Hyun inferred that the students understood the concept in a given situation, even if the answer was incorrect. The reason for their positive evaluations was that students could grasp the concept included in the given situation and apply it to real-world problem posing. To Seo and Hyun, an incorrect answer in problem posing was a trivial matter.

\section{DISCUSSION}

The current study contains an analysis of the problem posing SMK, KCT, and KCS of four teachers. The results of this study indicate that participants were aware of the importance of problem posing, knew the difference between problem generation and problem reformulation, and understood some variation of its definition. Their problem-posing results in terms of their problem generation and problem reformulation show their similar SMK. On the other hand, there was a discrepancy between the participants' teacher knowledge and their actual problem posing; their posed problems did not reflect their knowledge of problem posing. With regard to KCT, teachers noted that there are several difficulties and limitations teachers encounter when attempting to incorporate problem posing in the current education setting, such as the limited time available during class periods and the limited examples of problem posing in textbooks. With regard to KCS, all the participants had a positive perspective of problem posing's influence on students' mathematical proficiency. However, there was a difference between the teachers in terms of how they perceived the importance of problem solving in problem posing, and this difference impacted their assessment of problem posing. Because teacher knowledge influences actual teaching performance and student learning, it is necessary to support teachers' professional development.

The findings in this study show that there is a disconnect between teachers' teacher knowledge and their teaching practices. The types of problems the teachers posed were different from those they mentioned when discussing the various types of problem posing. One reason for this discrepancy might be due to the limited 
number of posed problems the participants were required to pose during the study. Perhaps if the teachers had been prompted to provide additional posed problems, they would have used the opportunity to pose a greater variety of problems. To effectively teach problem posing, teachers must have extensive and comprehensive knowledge of and experience in the problem-posing process. Lack of knowledge and experience limits teachers' actual teaching practice (Barlow \& Cates, 2006). Because the participants in the current study each had no more than five years of teaching experience, this experiential prerequisite may have been a significant factor impacting their problem-posing teaching practices. Furthermore, due to the participants' limited teaching experience, their undergraduate-level courses in problem-posing likely had a relevant impact on their overall teacher knowledge of problem posing as well. In fact, researchers have shown that the mathematics education courses pre-service teachers take have a critical influence on the development and improvement of their SMK and have a lasting impact on those individuals' teacher knowledge (Chen, Dooren, Chen, \& Verschaffel, 2011; Crespo, 2003). The essential takeaway from this information is that what teachers were taught consistently impacts their teaching. If teachers received limited or no instruction in using and teaching problem posing when they were pre-service teachers, they may struggle with posing problems or teaching problem posing when they become in-service teachers. Therefore, professional preparation for preservice teachers also needs to be considered to address problem-posing teaching readiness.

In addition, the teachers' teaching practices did not seem to well reflect their KCT and KCS due to the limitations found in the education setting in their classrooms. Regardless of the teachers' KCT and KCS of problem posing for students' mathematics performance, they were unable to prioritize problem posing as a result of various constraints within the educational settings in their classrooms such as limited time to teach problem posing and textbook content. One reason they gave for the difficulties experience in successful problem-posing implementation was they did not know how to provide diverse types of problem-posing activities. Teachers need to be challenged and provided with continuous opportunities to engage in problemposing activities and learn how to effectively implement such activities into classroom instruction (Crespo, 2003). Once again, the difficulties these teachers discussed during the study convey the importance of professional development that will help improve teachers' effective teaching practices of problem posing.

Despite the acknowledgement among researchers and educators that there is a troublingly low-level of teacher knowledge in problem posing and despite the recommendation and advocation of curriculums that incorporate various forms of problem posing in classrooms, professional preparation for pre-service teachers and professional development for in-service teachers have been insufficient and lacking. Problem posing itself should be considered an important mathematical activity in the professional preparation and development of teachers. Providing professional preparation in problem posing to pre-service teachers enables them to begin building their concrete teacher knowledge in problem posing, and administering professional development to in-service teachers can equip those teachers with the experience and skills to connect their teacher knowledge with actual teaching practices. This study is a preliminary analysis in understanding teacher knowledge in problem posing, which is also related to teaching practice. Follow up studies are necessary to examine the effects of professional preparation on pre-service teachers' teacher knowledge and practice in problem posing as well as the effects of professional development on in-service teachers' teacher knowledge and practices in relation to problem posing.

\section{Disclosure statement}

No potential conflict of interest was reported by the authors.

\section{Notes on contributors}

Yujin Lee - Texas A\&M University, USA.

Robert M. Capraro - Texas A\&M University, USA.

Mary Margaret Capraro - Texas A\&M University, USA. 


\section{REFERENCES}

Anfara Jr, V. A., Brown, K. M., \& Mangione, T. L. (2002). Qualitative analysis on stage: Making the research process more public. Educational Researcher, 31(7), 28-38. https://doi.org/10.3102/0013189X031007028

Ball, D. L. (1990). The mathematical understandings that prospective teachers bring to teacher education. The Elementary School Journal, 90(4), 449-466. https://doi.org/10.1086/461626

Ball, D. L., Hill, H. H., \& Bass, H. (2005, Fall). Knowing mathematics for teaching: Who knows mathematics well enough to teach third grade, and how can we decide? American Educator, 14-46.

Ball, D., Thames, M., \& Phelps, G. (2008). Content knowledge for teaching: What makes it special? Journal of Teacher Education, 59, 389-407. https://doi.org/10.1177/0022487108324554

Barlow, A. T., \& Cates, J. M. (2006). The impact of problem posing on elementary teachers' beliefs about mathematics and mathematics teaching. School Science and Mathematics, 106(2), 64-73. https://doi.org/10.1111/j.1949-8594.2006.tb18136.x

Bernardo, A. B. (2001). Analogical problem construction and transfer in mathematical problem solving. Educational Psychology, 21(2), 137-150. https://doi.org/10.1080/01443410020043841

Bonotto, C. (2013). Artifacts as sources for problem-posing activities. Educational Studies in Mathematics, 83(1), 37-55. https://doi.org/10.1007/s10649-012-9441-7

Brown, S. I., \& Walter, M. I. (1990). The art of problem posing (2nd ed.). Hillsdale, NJ: Erlbaum.

Cai, J., \& Hwang, S. (2002). Generalized and generative thinking in US and Chinese students' mathematical problem solving and problem posing. The Journal of Mathematical Behavior, 21(4), 401-421. https://doi.org/10.1016/S0732-3123(02)00142-6

Cankoy, O. (2010). Mathematics teachers' topic-specific pedagogical content knowledge in the context of teaching $\mathrm{a}^{\wedge} 0,0$ ! and $\mathrm{a} \div 0$. Educational Sciences: Theory and Practice, 10, 749-769.

Chen, L., Van Dooren, W., \& Verschaffel, L. (2011). An investigation on Chinese teachers' realistic problem solving abilities and beliefs. Journal of Mathematics Education, 4(2), 80-96.

Crespo, S. (2003). Learning to pose mathematical problems: Exploring changes in preservice teachers' practices. Educational Studies in Mathematics, 52, 243-270. https://doi.org/10.1023/A:1024364304664

Crespo, S., \& Sinclair, N. (2008). What makes a problem mathematically interesting? Inviting prospective teachers to pose better problems. Journal of Mathematics Teacher Education, 11, 395-415. https://doi.org/10.1007/s10857-008-9081-0

Darling-Hammond, L. (2000). Teacher quality and student achievement: A review of state policy evidence. Educational Policy Analysis Archives, 8(1), 1-44. https://doi.org/10.14507/epaa.v8n1.2000

English, L. D. (1998). Children's problem posing within formal and informal contexts. Journal for Research in Mathematics Education, 29(1), 83-106. https://oi.org/10.2307/749719

Even, R. (1993). Subject-matter knowledge and pedagogical content knowledge: Prospective secondary teachers and the function concept. Journal for Research in Mathematics education, 24(2), 94-116. https://doi.org/10.2307/749215

Grundmeier, T. (2003). The effects of providing mathematical problem posing experiences for $K$ - 8 preservice teachers: Investigating teachers' beliefs and characteristics of posed problems (Unpublished doctoral dissertation). University of New Hampshire.

Hauk, S., Toney, A., Jackson, B., Nair, R., \& Tsay, J. (2014). Developing a model of pedagogical content knowledge for secondary and post-secondary mathematics instruction. Dialogic Pedagogy: An International Online Journal, 2, 16-40. https://doi.org/10.5195/DPJ.2014.40

Hill, H. C., Ball, D. L., \& Schilling, S. G. (2008). Unpacking pedagogical content knowledge: Conceptualizing and measuring teachers' topic-specific knowledge of students. Journal for Research in Mathematics Education, 372-400.

Hurrell, D. (2013). What teachers need to know to teach mathematics: An argument for a reconceptualised model. Australian Journal of Teacher Education, 38(11), 53-64. https://doi.org/10.14221/ajte.2013v38n11.3

Koichu, B., Harel, G., \& Manaster, A. (2013). Ways of thinking associated with mathematics teachers' problem posing in the context of division of fractions. Instructional Science, 41(4), 681-698. https://doi.org/10.1007/s11251-012-9254-1 
Lannin, J., Webb, M., Chval, K., Arbaugh, F., Hicks, S., Taylor, C., \& Bruton, R. (2013). The development of beginning mathematics teacher pedagogical content knowledge. Journal of Math Teacher Education, 16, 403-426. https://doi.org/10.1007/s10857-013-9244-5

Lee, Y. (2012). An analysis of students' mathematical problem posing (Unpublished master's thesis). Ewha Womans University, Seoul, Korea.

Leung, S. S., \& Silver, E. A. (1997). The role of task format, mathematics knowledge, and creative thinking on the arithmetic problem posing of prospective elementary school teachers. Mathematics Education Research Journal, 9(1), 5-24. https://doi.org/10.1007/BF03217299

Merriam, S. B. (1998). Qualitative research and case study applications in education. Revised and expanded from" Case Study Research in Education."San Francisco, CA: Jossey-Bass Publishers.

Mestre, J. (2002). Probing adults' conceptual understanding and transfer of learning via problem posing. Applied Developmental Psychology, 23, 9-50. https://doi.org/10.1016/S0193-3973(01)00101-0

National Council of Teachers of Mathematics. (2000). Principles and standards for school mathematics. Reston, VA: Author.

National curriculum of Korea (2015). 수학과 교육과정 [The national curriculum of mathematics], 교육부 고시 제2015-74호 [별책 8], Korea: Author.

National Research Council. (2005). How students learn: History, mathematics, and science in the classroom. Washington, DC: Division of Behavioral and Social Sciences and Education, National Research Council of the National Academies.

Nicolaou, A. A., \& Philippou, G. N. (2007). Efficacy beliefs, problem posing, and mathematics achievement. In Proceedings of the $V$ Congress of the European society for research in mathematics education (pp. 308317)

Ozden, M. (2008). The effect of content knowledge on pedagogical content knowledge: the case of teaching phases of matters. educational sciences: Theory and Practice, 8(2), 633-645.

Patton, M. Q. (2015). Qualitative research and methods: Integrating theory and practice. Thousand Oaks, CA: Sage.

Pelczer, I., \& Rodríguez, F. G. (2011). Creativity assessment in school settings through problem posing tasks. The Mathematics Enthusiast, 8(1), 383-398.

Pelczer, I., \& Rodríguez, F. G. (2011). Creativity assessment in school settings through problem posing tasks. The Mathematics Enthusiast, 8(1), 383-398.

Priest, D. J. (2009). A problem-posing intervention in the development of problem-solving competence of underachieving, middle-year students (Unpublished Doctoral dissertation). Queensland University of Technology, Brisbane, Australia.

Quinn, R. J. (1997). Effects of mathematics methods courses on the mathematical attitudes and content knowledge of preservice teachers. The Journal of Educational Research, 91(2), 108-114. https://doi.org/10.1080/00220679709597528

Rizvi, N. F. (2004). Prospective teachers' ability to pose word problems. International Journal for Mathematics Teaching and Learning, 12, 1-22.

Rowan, B., Correnti, R., \& Miller, R. J. (2002). What large-scale survey research tells us about teacher effects on student achievement: Insights from the Prospects Study of elementary schools. Teachers College Record, 104, 1525-1567. https://doi.org/10.1111/1467-9620.00212

Rowland, T., Huckstep, P., \& Thwaites, A. (2003). The knowledge quartet. In J. Williams (Ed.), Proceedings of the British society for research into learning mathematics, 23(3), 97-103.

Schmidt, D. A., Baran, E., Thompson, A. D., Mishra, P., Koehler, M. J., \& Shin, T. S. (2009). Technological pedagogical content knowledge (TPACK) the development and validation of an assessment instrument for preservice teachers. Journal of Research on Technology in Education, 42(2), 123-149. https://doi.org/10.1080/15391523.2009.10782544

Shulman, L. (1986). Those who understand: Knowledge growth in teaching. Educational Researcher, 15(2), 414. https://doi.org/10.3102/0013189X015002004

Silver, E. A. (1994). On mathematical problem posing. For the Learning of Mathematics, 14(1), 19-28. 
Singer, F., \& Voica, C. (2012). A problem-solving conceptual framework and its implications in designing problem-posing tasks. Educational Studies in Mathematics, 83(1), 9-26. https://doi.org/10.1007/s10649012-9422-x

Stein, M., Smith, M., Henningsen, M., \& Silver, E. (2000). Implementing standards-based mathematics instruction: A casebook for professional development. New York, NY: Teachers College Press.

Stickles, P. (2006). An analysis of secondary and middle school teacher's mathematical problem posing (Unpublished doctoral dissertation). Indiana University.

Stickles, P. (2011). An analysis of secondary and middle school teachers' mathematical problem posing. Investigations in Mathematics Learning, 3(2), 1-34. https://doi.org/10.1080/24727466.2011.11790301

Strauss, A., \& Corbin, J. (1990). Basics of qualitative research: Grounded theory procedures and techniques. Newbury Park, CA: Sage.

Turner, D. W. (2010). Qualitative Interview Design: A Practical Guide for Novice Investigators. The Qualitative Report, 15(3), 754-760.

Valanides, N. (2000a). Primary student teachers' understanding of the particulate nature of matter and its transformations during dissolving. Chemical Education Research and Practice, 1, 249-262. https://doi.org/10.1039/A9RP90026H

Van Harpen, X. Y., \& Presmeg, N. C. (2013). An investigation of relationships between students' mathematical problem-posing abilities and their mathematical content knowledge. Educational Studies in Mathematics, 83(1), 117-132. https://doi.org/10.1007/s10649-012-9456-0

Wilson, S., Floden, R., \& Ferrini-Mundy, J. (2001). Teacher preparation research: Current knowledge, gaps, and recommendations. A research report prepared for the U.S. Department of Education. Seattle, WA: University of Washington, Center for the Study of Teaching and Policy in collaboration with Michigan State University.

Wilson, S., Floden, R., \& Ferrini-Mundy, J. (2002). Teacher preparation research: An insider's view from the outside. Journal of Teacher Education, 53, 190-204. https://doi.org/10.1177/0022487102053003002 


\section{APPENDIX $A^{1}$}

2. 아레의 보기를 바탕으로 다양한 중류의 수학 문제를 만들어 보시오.

$<$ 브기>

친구들이 나연이네 집에 놀러왔다. 나연이네 어머니는 아이들에게 쿠키를 구워

주려고 한다. 한 사랍 당 쿠키를 (4개)씩 주려고 했는데, 미리 구워둔 쿠키가 3 개

밖에 없어서 어머너는 쿠키를 더 구워야 한다.

<꼰제 만듔기>

$\checkmark$

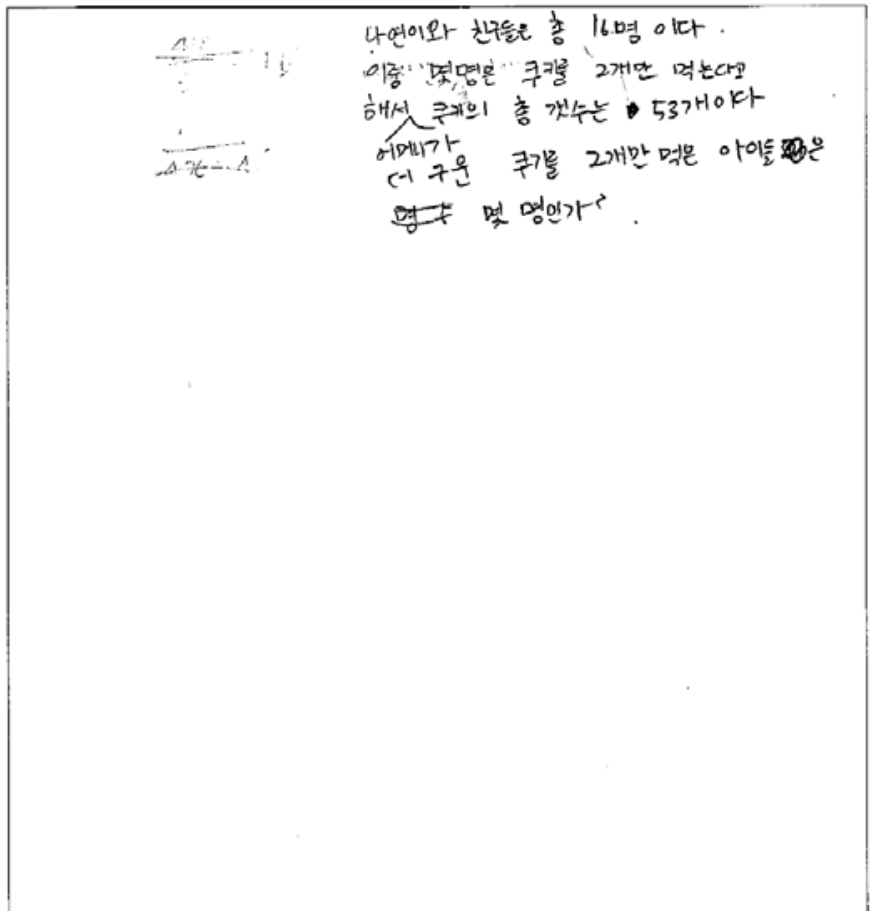

1 [Transcript]

Question: Nayeon's friends come over to her house. Her mom is going to bake cookies for them. She wants to give four cookies to each child, but so far she has only baked three cookies. Therefore, she has to bake more cookies.

Result of problem posing: The total number of Nayeon and her friends are 16 . Some of them eat only 2 cookies. The total number of cookies are 53 . How many kids eat only 2 cookies? 


\section{APPENDIX $B^{2}$}

4. (1) 다음 문제클 풀어 보시오.

<문제>

00 뷔페는 1 인당 2 만원의 요금올 받는다. 미리 예약을 했을 경우, 1 인당 요금을 5000 원씩 할인해 준다. 유진이네 가족은 뷔페에 가기위해 $\circ \circ$ 뷔페에 예약을 했 다. 집예서 출발하기 직전, 합아버지와 할머니를 모시고 가기로 하였다. 식사를 한 후, 계산을 하려고 할 때, 할아버지와 할머니는 예약자 명단에 없기 때문에 할인을 받을 수 없다는 사실을 알게 되었다. 결국, 총 115000 원의 요금을 냈다. 미리 예약이 되어있었던 사람온 몇 명인가? 5 영 예약,

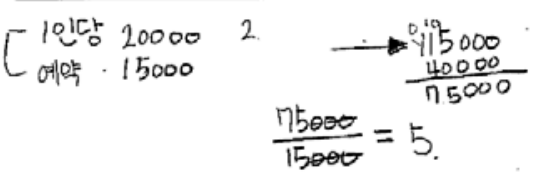

(2) 위의 문제를 변형하여 또 다론 수학문제를 다양하게 만들어 보시오.

\begin{tabular}{|c|}
\hline 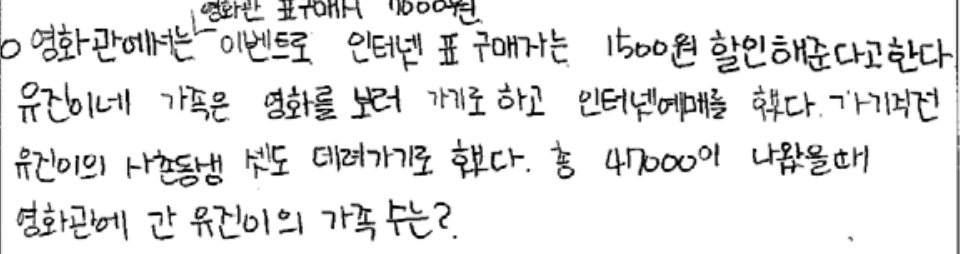 \\
\hline- , \\
\hline
\end{tabular}

2 [Transcript]

Question: The buffet restaurant charges 20,000 won (KRW) per person. They discount 5,000 won per reserved customer. Eugene's family reserved a table at this restaurant. Right before they left for the restaurant, they decided to take Eugene's grandparents along with them. When they were about to pay the bill after enjoying their meal, they found out that Eugene's grandparents could not get a discount since their names were not on the reservation list. In the end, they paid 115,000 won for everyone. In this case, how many people had made a reservation?

Result of problem posing: The movie theater's ticket price is 7,000 won. A person can book on-line tickets at a 1,500 won discount for each ticket. Eugene's family booked tickets. Before they leave the house, they made a decision to go with Eugen's cousin. The total price of the ticket is 4,7000. How many family members watched the movie? 


\section{APPENDIX C}

Examples of Teacher Knowledge Codes

\begin{tabular}{ll}
\hline Utterance & Code \\
\hline A teacher has knowledge about problem posing. & TKP \\
\hline A teacher does not have knowledge about problem posing. & TKN \\
\hline A teacher believes positive perception about problem posing. & TBP \\
\hline A teacher believes negative perception about problem posing. & TBN \\
\hline A teacher has positive perception about applying problem posing into class. & TAP \\
\hline A teacher has negative perception about applying problem posing into class. & TAN \\
\hline Students have knowledge about problem posing. & SKP \\
\hline Students do not have knowledge about problem posing. & SKN \\
\hline Students believe positive perception about problem posing. & SBP \\
\hline Students believe negative perception about problem posing. & SBN \\
\hline Students have positive perception about applying problem posing into class. & SAP \\
\hline Students have negative perception about applying problem posing into class. & SAN \\
\hline A teacher has knowledge about problem posing in textbook. & CKP \\
\hline A teacher does not have knowledge about problem posing in textbook. & CKN \\
\hline A teacher believes positive perception about problem posing in textbook. & CBP \\
\hline A teacher believes negative perception about problem posing in textbook. & CBN \\
\hline A teacher has positive perception about applying problem posing in textbook into class. & CAP \\
\hline A teacher has negative perception about applying problem posing in textbook into class. & CAN \\
\hline
\end{tabular}

